University of Maryland Francis King Carey School of Law

DigitalCommons@UM Carey Law

1992

\title{
Ignoring History: The Liability of Ships' Masters, Innkeepers and Stablekeepers Under Roman Law
}

David S. Bogen

University of Maryland School of Law, dbogen@law.umaryland.edu

Follow this and additional works at: https://digitalcommons.law.umaryland.edu/fac_pubs

Part of the Legal History Commons, and the Torts Commons

\section{Digital Commons Citation}

Bogen, David S., "Ignoring History: The Liability of Ships' Masters, Innkeepers and Stablekeepers Under Roman Law" (1992). Faculty Scholarship. 767.

https://digitalcommons.law.umaryland.edu/fac_pubs/767

This Article is brought to you for free and open access by the Francis King Carey School of Law Faculty at DigitalCommons@UM Carey Law. It has been accepted for inclusion in Faculty Scholarship by an authorized administrator of DigitalCommons@UM Carey Law. For more information, please contact smccarty@law.umaryland.edu. 


\title{
Ignoring History: The Liability of Ships' Masters, Innkeepers and Stablekeepers Under Roman Law
}

\author{
by DAVID S. BOGEN*
}

Roman law is rarely taught in American law schools, although it has had an unequalled impact on the legal systems of the world. Contemporary issues dominate the elective curriculum-gender, race, the environment, and the impact of technological change together with responses to those problems in the legal clinic practice and jurisprudential theory. ${ }^{1}$ But any attempt to deal with today's problems without an historical sense threatens to compound the errors of the past. Proposals to change or retain laws may be misdirected when they focus on contemporary justifications without considering history. Roman law illustrates some of the difficulties created by ignoring history, while it also provides perspective on the common law and examples for studies in legal reasoning. This paper deals with one small issue of Roman law that provides such an object lesson-the confusion and conflict in the Digest on the obligations of ships' masters, innkeepers, and stablekeepers.

The preeminent source for our knowledge of Roman law is Justinian's Digest. ${ }^{2}$ It devoted two of its four hundred thirty-two titles to actions against ships' masters, innkeepers and stablekeepers. ${ }^{3}$ However, the provisions in those titles seem to conflict. One passage says that innkeepers and ships' masters are liable for the acts of their customers, but another passage says that they are not. One passage

*Professor, University of Maryland School of Law, Baltimore, Md. Tony Weir commented on an earlier draft of this piece during a brief visit at Maryland, saving the author from untold mistakes, but he cannot be held responsible for those that remain. I have also profited from the advice of my colleagues Oscar Gray, Alan Hornstein, Mark Sargent, Ted Tomlinson and Gordon Young. Tracy Downing, Celeste Hunter Robinson and John Connolly served as research assistants.

1. Even English legal history, the fount of the American legal system, receives only incidental mention in most of legal education.

2. The Digest of Justinian, (4 vols.; translation edited by Alan Watson with Latin text edited by Theodor Mommsen with the aid of Paul Krueger; Philadelphia: University of Pennsylvania Press, 1985). Like Tribonian, Watson directed a group of scholars in this effort, and there are distinct differences in style among them.

3. D. 4.9 and D. 47.5. Citations to Justinian's Digest are traditionally made with the abbreviation D. and the numbers of book, title, fragment, and paragraph. The first paragraph is the principium abbreviated pr., so $\S 1$ is really the second paragraph. Other titles in the Digest also deal with ships' masters, innkeepers and stablekeepers, but they either make only passing references (D.19.2.13.1,2; D.19.2.31; D.19.5.1; D.44.7.5.6; 47.2.14.17) or focus entirely on ships' masters (D.14.1,2). 
states that innkeepers must accept travelers while another says that innkeepers may choose whether to receive them. This article attempts to unravel these contradictions. It concludes that the lack of any authoritative rule on the obligation of innkeepers to serve the public led to the inconsistent Digest statements. The confusion resulted from attempts to give reasons for the variety of legal rules on ships' masters, innkeepers and stablekeepers without considering the historical development of those rules.

\section{A Note on Historical Development}

Roman law is the law of an entity that changes over a thousand year period from a small city ruled by a king to a growing republic to an empire surrounding the Mediterranean sea. The law also changed significantly, and some knowledge of its historical development is necessary to understand the conflict in the texts.

The first record of Roman law is the Twelve Tables-a record of customary law from about 450 B.C. of which only fragments survive. ${ }^{4}$ Private citizens enforced obligations under this law by making a claim before the magistrate, or praetor, an official elected annually. The praetor decided whether the plaintiff's claim was in the correct form derived from the Twelve Tables and appointed the judge or judges to hear it. These actions pursuant to the promulgated law were called legis actiones. $^{5}$ Later statutes, such as the lex Aquilia of 286 B.C. which introduced a more comprehensive system of law on injury to property, also provided for enforcement by legis actiones. ${ }^{6}$ But decisions under the legis actiones became technical and lacked the flexibility to deal with new situations. During the second century B.C., the praetor was freed from the constraints of the legis actiones and issued his own form which framed the issue for the judge or iudex, who was bound by the terms of the praetor's formula. Ultimately, the praetor issued formulae for new causes of action and might even refuse to grant a formula for a statutorily based claim which he thought unfair. ${ }^{7}$ The praetor's behavior might be analogized to the English courts of Equity which did not challenge the validity of the common law, but developed new remedies which were unavailable at common law or enjoined persons from pursuing common law remedies. Unlike the English Equity court, the Roman praetor faced no competition for business from other courts and his decisions became central to Roman private law.

4. Wolfgang Kunkel, An Introduction to Roman Legal and Constitutional History (trans. J.M. Kelly, 2d ed.; Oxford: Clarendon Press, 1973) p. 23. See D.1.2.4. Book One of the Digest is on the Origin of Law. It provides some institutional history of Roman law, but provides little in the way of doctrine.

5. The Institutes of Gaius (trans. W.M. Gordon and O.F. Robinson from Latin text of Seckel and Kuebler; Ithaca: Cornell University Press, 1988) p. 407 [IV.11.].

6. Kunkel, supra note 4 at 31. See D.9.2.

7. Kunkel, supra note 4 at 85-91; Gaius, supra note 5 at 427 [IV:30]. 
On taking office, praetors announced in an "edict" the principles of law they would follow. Although each praetor was bound to follow his own edict, the next praetor could promulgate a different rule. Nevertheless, successive praetors usually adopted most of the principles of their predecessors. Around 130 A.D., the Emperor Hadrian instructed Salvius Julianus to consolidate the edicts of the praetors into a single edict, which could be changed only by the emperor. ${ }^{8}$ Although the original text of Julian's revision of the edict has been lost, Professor Otto Lenel reconstructed it. This reconstruction has been widely accepted despite criticism of some particulars. ${ }^{9}$

The praetors rarely had legal training, but they could get advice from private individuals trained in the law. Litigants also could request advice from these jurists. Some of the jurists' responses eventually became part of the Digest; for example, Alfenus reported responses of Servius Sulpicius Rufus in the first century B.C. ${ }^{10}$ By that time, the jurists not only responded to actual cases, but created and discussed hypotheticals as well. ${ }^{11}$ Developing out of this tradition, jurists began to write extensive commentaries on the interpretation and application of the laws. By the beginning of the third century A.D., Ulpian and others wrote commentaries that included extensive references to the work of previous jurists. Such commentary became particularly useful as the Roman legal system became an imperial bureaucracy.

The two-stage proceeding of obtaining a formula from the praetor which told the judge what issues to decide was gradually replaced by the cognitio, a unitary procedural system in which the magistrate heard the whole case. Despite changes in procedure and new laws promulgated by the Emperor, the commentaries from earlier periods remained essential expositions of the law's substance. Multiple copies of the most popular works were made by scribes. They were consulted by government officials and studied in schools. These commentaries were not historical curiosities, but living guides that needed constant revision. Like subsequent editions of Blackstone, Kent, Story and Williston where the original author's name becomes part of the title and the later editors get little recognition, new editions of the classical Roman jurists gave

8. R.W. Leage, Roman Private Law (3d ed. A.M. Prichard; New York: St. Martin's Press, 1967) pp. 21-30. Kunkel, supra note 4 at 90-94. The date of 131 A.D. is often given for Julian's completion of the edict, but Honoré suggests that it is an open question. Tony Honoré, Gaius (Oxford: Clarendon Press, 1962) pp. 54-55.

9. Otto Lenel, Das Edictum Perpetuum (Leipzig: B. Tauchnitz, 1927). Lenel's reconstruction contained at least 292 entries. For an English translation of the Perpetual Edict, see Ancient Roman Statutes (trans. Allan Chester Johnson, Paul Robinson Coleman-Norton, Frank Card Bourne; Austin: University of Texas Press, 1961) pp. 18395.

10. D.19.2.31.

11. See Bruce W. Frier, The Rise of the Roman Jurists (Princeton: Princeton University Press, 1985). 
little credit to the later editors (who may not have completely understood the original author). Users might add notes or revisions on the original papyrus, which might in turn be copied as part of the manuscript with no indication that they were not part of the original. Additions to and alterations of the original text are called "interpolations." 12 These texts from the classical era as they passed through 300 years of anonymous revision were the primary authorities excerpted in the Digest.

In 530 A.D., the Emperor Justinian commanded his quaestor Tribonian and other legal scholars under Tribonian's direction to compile in fifty short books a single work out of the writings of ancient authorities. ${ }^{13}$ The scholars were directed to excerpt the old works to eliminate repetition, obsolete discussion, and inconsistency. They were to correct mistakes of the authorities and improve their expression. ${ }^{14}$ They completed their task in 3 years, condensing more than $3,000,000$ lines into a work of 150,000 lines. ${ }^{15}$ The fifty books of the Digest were subdivided into titles for each subject treated. Within each title, the compilers placed fragments from various authors with inscriptions naming the author and the book where the statements had been found.16 Justinian then commanded that this Digest have the force of law. Any texts not contained in the Digest could not be offered in argument in court. Ultimately nearly all the works of the old authorities on Roman

12. See H.F. Jolowicz, Historical Introduction to the Study of Roman Law (2d ed., Cambridge: University Press, 1954 reprinted 1961) p. 497-98; Fritz Schulz, History of Roman Legal Science (Oxford: Clarendon Press, 1963) p. 142; and Kunkel, supra note 4 at 137. Severe internal and external crises wracked the empire for much of the third century A.D., ending in an absolute monarchy. In 395 A.D., the empire was divided into the Eastern Roman empire and the Western empire. The Western empire where Latin remained the dominant language moved away from the classical system of Roman law which prevailed in the beginning of the third century A.D. The classical law was preserved in the east where the law schools flourished, but Greek was the language of the Eastern empire. The two empires were united once more under Justinian, only to dissolve upon his death. Max Kaser, Roman Private Law (trans. Rolf Dannenbring, 2d ed. Durban: Butterworths, 1968) pp. 3-5.

13. A book originally was a scroll. The book with a spine and pages came into general use in the third century A.D. Justinian's Institutes (trans. Peter Birks \& Grant McLeod with Latin text of Paul Krueger; Ithaca: Cornell University Press, 1987) p. 9. Most of the ancient authorities were classical jurists who wrote in the late second and early third century. Their books would often have been scrolls of limited length. But the length of books with pages also remained limited for many years-the Digest books averaged about three thousand lines each which is 37.5 printed pages in the Watson edition. In effect, the book was a unit of length in ancient Rome, so Tribonian knew just how much he would have to condense the material when Justinian told him that the Digest was to be in fifty books.

14. I Watson, supra note 2 at xlvi-xlix. The scholars were Tribonian, Constantinus, Theophilus, Dorotheus, Anatolius and Cratinus. They were assisted by eleven named barristers who also acted as counsel in cases heard before the court in the east. Justinian, De Confirmatione Digestorum in Watson, supra at lviii-lix.

15. Id. at lvi.

16. Id. at lix. 
law have been lost, and only those selections excerpted in the Digest have survived.

\section{The Conflict in the Digest Texts}

Justinian, in his confirmation of the Digest, claimed that it had no inconsistencies.

As for any contradiction occurring in this book, none such has found a place for itself, and none will be discovered by anyone who reflects acutely upon the modes of diversity. On the contrary, something will be found, even if obscurely expressed, which removes the objection of inconsistency, gives the matter a different aspect, and passes outside the limits of discrepancy. ${ }^{17}$

Despite this claim, the Digest contains a number of inconsistent passages, including those found in the two separate titles of the Digest on the liability of nautae, caupones et stabularii for losses suffered by their customers. "Nautae" are ships' masters. ${ }^{18}$

\section{Id. at lxi.}

18. The translation of "nautae" reveals the difficulties in dealing with another language. There is simply no adequate way to translate nautae in this context. Literally, it means seamen. But the praetor, the official who issues the edit, made it clear that a special definition was involved. "The praetor says: 'seamen.' We ought to understand a seaman to be one who manages the ship, although all are called seamen who are in the ship in order to sail it. But the praetor is thinking only of the person in charge." D.4.9.1.2. Geoffrey McCormack, the translator of D.4 in the Watson edition quoted above, rendered nauta literally as "seaman," leaving it in quotes whenever nauta referred to the special definition above. Unfortunately, "seaman" would lose the sense of vicarious liability if used in an extended article like this one.

The special definition for nauta in D.4.9.1.2 says the nauta is one who manages the ship (qui navem exercet) and that the praetor is thinking only of the person in charge (de exercitore). There are two candidates for that position-the magister navis and the exercitor-but neither one alone is satisfactory. Nautae probably includes both of them together, depending on the structure of authority on the particular trip.

The magister navis is the person in physical charge of the vessel. The exercitor is "the maritime entrepreneur, the person with the prime economic interest in the ship's operations, the man who gives orders to the captain." I Watson, supra at 415 . Tony Weir, translator of D.14, renders exercitor as "shipowner" while explaining that there is no precise English equivalent for the Latin term, since the exercitor may not in fact be the owner of the ship. "Shipowner' in this connection designates the person to whom all the income and revenues come, even if he does not actually own the ship: He may have hired it from the owner for a lump sum or for a fixed term or without limit of time." D.14.1.1.15.

A separate title of the Digest is devoted to the liability of the exercitor. D.14.1. As the person who appoints the magister navis, the exercitor is liable for the agreements of the captain within the scope of the authority he gave the captain. D.14.1.1.7. The exercitor is also liable for the delicts of the crew on board. D.14.1.1.2. But the Digest did not limit liability in D.4.9 or D.47.5 to the exercitor. After all, the liability of the exercitor derives from the magister navis. An action against one bars an action against the other. D.14.1.1.24. Furthermore, it is the magister navis who sues and is sued under the Rhodian law of jettison when cargo is jettisoned to save the ship. D.14.2.2pr. Finally, the definitions of innkeeper and stablekeeper in D.4.9 state that they comprise both those who carry on (exercent) the business of an inn or stable 


\section{"Caupones" are innkeepers. "Stabularii" are stablekeepers. ${ }^{19}$}

"Let Seamen, Innkeepers, and Stablekeepers Restore What They Have Received" is the caption for title 9 of Digest book 4. The first fragment under that title establishes the strict liability of ships' masters, innkeepers and stablekeepers for any damage or loss of their customers' goods. ${ }^{20}$ The ship's master is liable for damage or loss resulting from the acts of the passengers. "[H]e receives for safekeeping all the goods which have been brought onto the ship and . . . he ought to be liable for the acts not only of the crew but also of the passengers.' 21 The succeeding fragment adds, "just as an innkeeper is liable for the acts of travelers.' 22

D.4.9.1.1, the "operator's choice" paragraph, states in part that

and their managers. D.4.9.1.5. The parallel liability of the nautae, caupones and stabularii suggests a parallel interpretation of the status of persons covered by the terms. Thus, nauta in both D.4.9 and D.47.5 should be read to include both the exercitor and the magister navis.

J.A.C. Thomas translated nauta as "ship's master" in the title of D.47.5. "Ship's master" is the literal translation of magister navis, but the nauta is not just the magister navis. Most of the specific references to liability in D.47.5 specify the exercitor navis rather than the magister navis. Further, nauta must refer to someone other than the magister navis in D.4.9 because a fragment states that the nauta should only be placed under an obligation "through his own act or that of the master of the ship." D.4.9.1.2 (emphasis supplied).

Despite problems, this article translates nauta as "ship's master" to indicate the person or persons with effective charge of the ship. To avoid confusion, where not quoting another's translation, the article refers to the magister navis as the "captain" of the ship. Translating magister navis as "captain" is intended to convey the idea that "ship's master" is a broader term that refers to both the captain (magister navis) and to the shipowner (exercitor) where the captain acts within his authority.

19. Stabulum carried the dual meaning of stable and inn. The word may have begun as an inn with a stable, but it lost that restrictive meaning. Tönnes Kleberg, Hôtels, Restaurants et Cabarets dans L'Antiquité Romaine: Études historiques et philologiques (Uppsala: Almqvist \& Wiksells, 1957) pp. 18-19. See also Cassell's Latin Dictionary: Latin-English and English-Latin, S.V. "Stabulum." "Stabularii" was variously translated as stablekeepers, liverymen and innkeepers in Watson, supra note 2. "Stabularius" in D.3.2.4.2 was translated as a keeper of a tavern. Watson, supra note 2 at 83. Other authors also refer to stabularius as an innkeeper. W.C. Firebaugh, The Inns of Greece \& Rome: And a History of Hospitality from the Dawn of Time to the Middle Ages (Chicago: Pascal Covici, 1928) 119. D.4.9.5pr speaks of the stabularius receiving payment on account of beasts (jumentum) staying with him. Kleberg cites Digest 4.9 .5 as an example of the use of stabularius as a keeper of an inn with stables. Kleberg, supra at 28 . Nevertheless, the Digest chapters on liability of nautae, caupones et stabularii, D.4.9 and D. 47.5, translate stabularii as stablekeepers or liverymen. This seems the better translation in focusing on the stable in contrast to the caupones who operate inns. Much of the same rationale for holding the operator liable for lost property applies regardless whether the stables are part of the inn or have an independent identity.

20. D.4.9.1pr. See also D. 4.9.3.1.

21. D.4.9.1.8. See also D.4.9.3pr.

22. D.4.9.2. 
this strict liability is not too harsh because these businesses decide whom they will take.

The praetor says: "I will give an action against seamen, innkeepers, and stablekeepers in respect of what they have received and undertaken to keep safe, unless they restore it." This edict is of the greatest benefit, because it is necessary generally to trust these persons and deliver property into their custody. Let no one think that the obligation placed on them is too strict; for $i t$ is in their own discretion whether to receive anyone. ${ }^{23}$

One of the puzzles of this passage is the failure of the explanation to explain. The discretion of the operator of a business to refuse customers doesn't significantly mitigate the severity of the liability. Innkeepers and ships' masters often knew very little about the travelers who asked for their services. ${ }^{24}$ Choice in such constrained circumstances is not meaningful and provides no foundation for arguing that the liability is not too strict for the businessman.

The mystery of this explanation is compounded by another Digest section which denies both the innkeeper's right to refuse customers and his liability for their behavior. Title 5 of book 47 of the Digest, captioned "The Action for Theft Against Ships' Masters, Innkeepers, and Liverymen," sets forth the liability of those persons for theft committed by their employees, stating that the action is for twofold.25 But ships' masters are not liable for the behavior of their passengers. D.47.5.1.6, the "innkeeper's duty" paragraph, states that innkeepers are liable for thefts committed by their permanent lodgers, but not for theft by travelers because they cannot exclude the latter.

The innkeeper is answerable for the deeds of those whom he has in the inn to run the establishment as also of those who reside in the inn; he is not answerable for the acts of passing travelers. For an innkeeper or liveryman is not regarded as choosing his own traveler and cannot refuse those making a journey; but in a way, the innkeeper does select his permanent residents, since he does not reject them, and so should be answerable for what they do. In the case of a ship, there is no liability for the acts of passengers. ${ }^{26}$

Once more the explanation makes no sense. The distinction between the traveler and the lodger purportedly shows that the innkeeper is at fault for thefts committed by a long term lodger and not for those committed by the traveler. But the ship's master is not liable for the acts of his passengers although there is no indication he is bound to accept them. Further, fault is a poor explanation for double damages, because the employer may have no inkling of the

23. (emphasis supplied) D.4.9.1 pr.

24. D.14.1.1pr. If the traveler knew little about the character of the ship's master because of the need for haste in making arrangements, the same was likely to be true of the master's knowledge of the traveler.

25. D.47.5.1pr,2,6.

26. (emphasis supplied) D.47.5.1.6. 
character defect of his employees or his permanent lodgers. Finally , the liability is aberrational, for employers in other businesses do not have to pay double damages for thefts committed by their employees. Thus, the distinction between the types of customers the innkeeper must shelter and those he may refuse does not explain the imposition of double damages.

In short, the "operator's choice" paragraph and the "innkeeper's duty" paragraph conflict on the innkeeper's duty to serve the traveler; they do not justify the liability rules they purportedly explain; and those liability rules themselves appear inconsistent. The remainder of this paper attempts to explain the apparent inconsistency in liability rules, the weaknesses of the explanations for those rules and the conflict in statements on the innkeeper's duty to accept travelers.

The search for answers to these puzzles leads from the Digest texts through the historical development of Roman law, the methodology of the compilers, and the analysis of interpolations which change the original texts.

\section{The Different Rules on Liability for Customer Losses - Actio Furti Adversus Nautae Caupones Stabularii and Actio de Recepto}

The first puzzle posed by the two titles on the liability of ships' masters, innkeepers and stablekeepers is why the texts contain different conditions of liability for customer losses-some saying they are liable to their customers for thefts committed by other customers while other passages state they are not liable for the misbehavior of their customers. The simplest explanation is that the texts refer to different actions.

Confusion arises because characteristics from one action are included in a title of the Digest apparently devoted to the other. The solution of this difficulty requires an excursion into the working methodology of the compilers and a discussion of the problems posed by the existence of yet a third action which had no separate title, the actio damni adversus nautas caupones et stabularios [actio damni a.n.c.s.], an action for damages to goods.

\section{A. Textual Differences Refer to Separate Actions}

Most scholars agree that there are at least two separate actionsthe actio furti adversus nautae caupones stabularios [hereinafter actio furti a.n.c.s.] and the actio de recepto-applicable to the liability of ships' masters, innkeepers and stablekeepers for losses suffered by their customers. ${ }^{27}$ This theory reconciles the conflicting liability rules, although it does not resolve whether innkeepers could refuse patrons.

27. Ferdinand Mackeldey, Handbook of the Roman Law (trans. Moses A. Dropsie; 
For the most part, the actions are found in different books of the Digest, dealing with very different concepts. Book 47 deals primarily with civil wrongs like theft, arson, swindling, defamation and robbery where the victim was often entitled to a twofold or fourfold recovery. The actio furti a.n.c.s. is described in title 5 of that book. It was quasi-delictual and permitted a twofold recovery. The victim must prove that the goods were stolen by the operator of the business, his employee, or, in the case of the inn, by a long term lodger. The justification offered emphasized the fault of the operator of the business in selecting dishonest employees, but the employee's dishonesty was conclusive proof of the employer's fault.

On the other hand, book 4 of the Digest deals largely with restitution. ${ }^{28}$ The first several fragments of Title 9 of that book describe the actio de recepto. That action is more contractual in nature and recovery is limited to the value of the goods lost or the amount by which they were damaged. The action was for failure to restore what had been received. The victim could recover from the operator of the business for loss even if the goods were stolen by a fellow passenger or traveler; indeed, the victim could recover without knowing how the goods were lost. Such strict liability could not be justified by any demonstrated fault of the defendant, but it protected against any possibility of dishonest operators.

Thus, the ship's master, the innkeeper or the stablekeeper were liable for damages in the actio de recepto for the acts of a customer which harmed another customer's goods, but they were not liable to pay the double damages of the actio furti a.n.c.s. for such acts.

\section{B. The Parallel to Related Actions: The Actio Furti and the Condictio Furtiva}

The perpetrator of a theft also faced two separate actions with different contours which applied to the same event. The general action against the thief was called the actio furti. It can be traced to the Twelve Tables. "The code, so far as can be seen, was in very large

Philadelphia: T. \& J.W. Johnson \& Co., 1883) p. 361, 378; Rudolph Sohm, The Institutes: History and System of Roman Private Law (3d ed.; trans. James Crawford Ledlie; Oxford: Clarendon Press, 1907 reprinted 1970 by Augustus M. Kelley, New York) p. 411; Paul Huvelin, Études D'Histoire du Droit Commercial Romain (Paris: Librarie du Recueil Sirey, 1929) pp. 115 et seq.; W.W. Buckland, A Manual of Roman Private Law (2d ed.; Cambridge: Cambridge University Press, 1939 reprinted 1957) pp. 309, 332; J.A. Crook, Law and Life of Rome (London: The Camelot Press Ltd., 1967) pp. 226-28; R.W. Leage, supra note 8 at 381, 422; Max Kaser, supra note 12 at 197-98.

28. This is not restitution in a technical sense of the word, but deals with nullifying an intervening event-"For under this head, the praetor helps men on many occasions who have made a mistake or been cheated, whether they have incurred loss through duress or cunning or their youth or absence." D.4.1.1. 
measure based on the idea of the right of an injured party to private vengeance." 29 If the thief was not caught in the act, the victim could obtain a monetary penalty, usually set at double damages. ${ }^{30}$ Under the Twelve Tables, if the victim caught the thief in the act, he could bring the thief before a magistrate who would hand the thief into the power of the victim to enslave or sell into slavery to foreigners. ${ }^{31}$ Sometime around the third century B.C., the penalty for manifest theft in the Twelve Tables was modified by the praetor's edict. ${ }^{32}$ "[T] was disapproved and an action for fourfold damages was created in the praetor's Edict." 33 Perhaps also the edict reflected a common practice by victims of accepting a ransom instead of killing or enslaving the thief. 34

The actio furti with its twofold or fourfold damages lay only against the thief and not his heirs. Further, multiple damages were of little effect against a poor defendant. The owner would normally be satisfied with return of the property. Indeed, the Twelve Tables provided that the stolen property belonged to the owner, so the owner could recover it in addition to collecting the multiple damages. ${ }^{35}$ The action for determination that the property belonged to the owner (vindicatio) was

29. Kunkel, supra note 4 at 27.

30. Id. at 28. "When anyone accuses and convicts another of theft which is not manifest, and no stolen property is found, judgment shall be rendered to compel the thief to pay double the value of what was stolen." Law 8 of Table II of the Twelve Tables, translated in Samuel Parsons Scott, Corpus Juris Civilis: The Civil Law, Vol. I (17 vols., Cincinnati: The Central Trust Company, 1932, reprinted New York: AMS Press, 1973) p. 62. "For non-manifest theft the Twelve Tables appointed a penalty of double damages, and this the praetor still retains." The Institutes of Gaius, supra note 5 at 377 [Book III, 190].

31. Kunkel, supra note 4 at 28. The Twelve Tables permit killing for manifest theft where the theft is committed at night (Table II, Law IV), where the thieves attempt to defend themselves (Table II, Law VI), or where the thief is a slave (Table II, Law V); otherwise they provide that thieves be given to the victim as slaves (Table II, Law V). See Table II of the Twelve Tables, translated in I Scott, supra note 30 at 58-62. Gaius wrote that "For manifest theft the penalty under the Twelve Tables was capital." Gaius, supra note 5 at 375 [III, 189]. Kunkel said that the victim of manifest theft could kill the thief after the magistrate handed the thief over to him. Zulueta said, however, that "poena capitalis" in Gaius here implied merely loss of status. Francis de Zulueta, The Institutes of Gaius: Part II Commentary (Oxford: Clarendon Press, 1953 reprinted 1963) p. 201.

32. J.M. Kelly, Roman Litigation (Oxford: Clarendon Press, 1966) p. 161.

33. Gaius, supra note 5 at 375-77 [III, 189]. Professor Kelly suggested that the distinction in furtum between manifestum and nec manifestum was based on the strength of the proof which explained the difference in penalty. Kelly, supra note 32 at $141-44$. Alternatively, he speculated that quadruple damages were reserved for offenses where the law had been ineffectual-and that furtum manifestum was either theft committed in daylight by groups so powerful that they would not submit to law or at night by thieves devoid of assets. Id. at 161-3.

34. Leage, supra note 8 at $\mathbf{4 0 5 .}$

35. Twelve Tables, Table II, Law XI, "Stolen property shall always be his to whom it formerly belonged." Scott, supra note 30 at 62. 
supplanted by a new action for the value of the property derived from a more general restitutionary type of action. "By the first century B.C., and probably earlier, the condiction became available in cases of outright theft, provided the owner could express his claim as a claim for a certain sum, quantity or thing." ${ }^{6} 6$ The owner could sue the thief in a condictio furtiva for the value of the stolen property. ${ }^{37}$ This was not a delict, but a quasi-contractual action serving to prevent unjust enrichment. The condictio furtiva lay against the thief's heirs to prevent them from profiting from his wrong.

In sum, the victim of a theft had two options for redress against the wrongdoer: an action for double damages for theft, the actio furti, ${ }^{38}$ and a separate action similar to restitution to recover the value of the item stolen, the condictio furtiva. If the property belonged to the customer of a ship's master, innkeeper or stablekeeper, the customer could also choose between two different actions against the operator of the premises: the actio furti a.n.c.s. with its double damages or the actio de recepto for the value of the item which was not restored. These actions forced the operator to seek reimbursement by bringing the actio furti or condictio furtiva against the thief.

\section{The Placement of Sections Relating to Furti in the Title Devoted to Actio de Recepto}

Most of the confusion over the existence of separate actions arises from the compilers' failure to keep them separated. D.47.5 (the Theft title) is captioned "The Action for Theft Against Ships' Masters, Innkeepers and Liverymen" and is devoted to the actio furti a.n.c.s. D.4.9 (the Restoration title) is captioned "Let Seamen, Innkeepers and Stablekeepers Restore What They Have Received," and it discusses the actio de recepto. Nevertheless, at least two fragments in the Restoration title, fragments 6 and 7, refer to the actio furti a.n.c.s. Indeed, despite Justinian's caution against repetition, virtually every issue discussed in the Theft title is contained in the last two fragments of the Restoration title. ${ }^{39}$ The major difference is that fragments 6 and 7 in the Restoration

36. John P. Dawson, Unjust Enrichment (Boston: Little, Brown and Company, 1951) p. 43.

37. Leage, supra note 8 at 384-86. The owner could also bring a vindicatio where the stolen property was found. The vindicatio was the older action, but it required the plaintiff to find and seize the property in question and bring it before the court. The condictio probably initially developed to deal with fungible property such as money where the exact property could not be determined, and it was brought to recover the value of the item. Although in theory all three actions were available to an owner whose property was stolen, the return of the property would satisfy both vindicatio and condictio. The greater ease in bringing this action led to its ultimate extension to situations where the goods were unique. Ultimately, it supplanted the vindicatio.

38. Justinian's Institutes, supra note 13 at 129 [Book IV, Title V, §3].

39. 47.5.pr, 1 is found in D.4.9.7pr, D.47.5.2 in D.4.9.7.1, D.47.5.3 in D.4.9.6.4, D.47.5.5 in D.4.9.7.4, and D.47.5.6 in D.4.9.6.3. D.47.5.4 is the only portion of 47.5 
title refer to both damage and theft, but the Theft title covers only theft. Filing fragments 6 and 7 in the Restoration title produces a direct conflict within the same title. ${ }^{40}$ Fragment 2 says "an innkeeper is liable for the acts of travelers," 41 but paragraph 3 of fragment 6 states that the innkeepers' liability for the behavior of those living in the inn does not apply "to one who is received as a passing guest, such as a traveler."42 The repetitious nature and confusing placement of fragments 6 and 7 resulted from difficulties in classifying the action for damages, problems created by the compilers' methodology, and a lapse in judgment or concentration.

\section{The Actio Damni A.N.C.S.}

Although the strict liability of the actio de recepto covered damage as well as loss, the double damages of the quasi-delictual actio furti a.n.c.s. applied only to the theft of the goods of a customer. (Furtum is Latin for theft.) The actio damni a.n.c.s. was the quasi-delictual action when the defendant's employee damaged a customer's goods.

Lenel thought that there was an edict for the actio damni a.n.c.s., and that it followed immediately after the edict on the lex Aquilia in Julian's Edict. ${ }^{43} \mathrm{He}$ pointed to book 18 of Ulpian's On the Edict, which discussed the actio damni a.n.c.s. in connection with the lex Aquilia and harm to another's personal property. Unlike Ulpian, however, the Digest compilers chose not to discuss the actio damni a.n.c.s. in connection with material dealing with the lex Aquilia and harm to property, topics they dealt with in book 9 of the Digest. ${ }^{44}$ They apparently thought the actio damni a.n.c.s. was more closely related to the other praetorial actions against ships' masters, innkeepers and stablekeepers.

Huvelin contended that there was no separate edict for the actio damni a.n.c.s. in Julian's time, because the Digest does not give it a

that deals with the receptum, pointing out that where the receptum lies, the nauta should have the suit for furti against the thief. That point is also made in D.4.9.4pr.

40. There may be enough of a transition so that the reader understands different actions are meant. Paragraph 1 of fragment 6 begins with the example of the operator of a ship or an inn who employs a slave owned by another. It poses the hypothetical of damage or theft by the slave of his owner's goods. Although the action for theftfurtum-or an action for damages-damnum-would normally lie against the slave's owner noxally, the operator is liable to the owner for the wrong done him by his own slave because it is an action in factum. Perhaps the specific reference to theft and damage is sufficient to indicate that the remaining discussion is addressing the actio furti a.n.c.s. and not the receptum.

41. D.4.9.2.

42. D.4.9.6.3.

43. Lenel, supra note 9 at $205[\$ 78]$.

44. D.9.1.1; D.9.2.1,3,5,7,9,11,13,15,17,21,23,25,27,29,35. See D.9.4.2,6,14; D.4.9.7; D.47.10.25; D.47.12.2; D.48.8.10 which relate to such harms. 
separate title. ${ }^{45}$ Huvelin argued that the actio damni a.n.c.s. was patterned on the formula associated with the actio furti a.n.c.s., noting that Ulpian added references to theft when discussing the liability of the nauta for damage to goods. ${ }^{46}$ The close relationship of the actio damni a.n.c.s. and the actio furti a.n.c.s. does not prove the actio damni was not a separate edict, for it is possible that the compilers simply believed that amalgamating the discussion of the actio damni a.n.c.s. with other actions in one title would help condense the material.

While Ulpian discussed the actio damni a.n.c.s. and the actio furti a.n.c.s. together in book 18 on damages to personal property, he discussed the actio furti a.n.c.s. alone in book 38 which dealt largely with edicts involving theft. Ulpian's book 38 was a major source for Digest book 47, and the excerpts on the actio furti a.n.c.s. from that book of Ulpian became the Theft title of the Digest. ${ }^{47}$ The problem is to explain why the compilers chose to place the fragments from Ulpian's book 18 which combined the discussion of the actio damni a.n.c.s. with the actio furti a.n.c.s. in a title devoted to the actio de recepto. That explanation involves a short excursion into the method used in compiling the Digest.

\section{The Methodology of the Compilers}

Tribonian divided the compilers into three committees. On the basis of the first works which each committee read and excerpted, the committees have subsequently been called the Sabinian, edictal and Papinian committees. ${ }^{48}$ Working with Alan Rodger, Professor Tony Honoré constructed a theory of the editorial process by which the

45. Huvelin, supra note 27 at 128.

46. Huvelin, supra note 27 at 127-35.

47. D.47.2.53,93; D.47.4.1; D.47.5; D.47.6.1,3; D.47.7.7. See D.13.1.6,10,12; D.39.4.12.

48. The theory of three subcommittees was proposed by F. Bluhme in "Die Ordnung der Fragmente in den Pandektentiteln," 4 Zeitschrift fur geschichtliche Rechtswissenschaft 256-474 (1818), reprinted in 6 Labeo 50 (1960). He observed that excerpts from distinct groups of classical writings tended to stand side by side within the individual Digest titles. These groups or "masses" appeared in a regular sequence in the titles, although the sequence began with different groups in different titles.

"It is as if the titles were hands of cards in which, so far as five cards out of every six were concerned, the player, when he looked at his cards, found that they were arranged in suits and, within each suit, in numerical order, but that in some hands hearts came first, in others spades and so on. Bluhme interpreted the 'suits' as masses and, within each suit, the numerical order as the order in which the commissioners were to read the works assigned to them."

Tony Honoré, Tribonian (London: Gerald Duckworth \& Co., 1978) p. 150. Bluhme's theory is generally accepted. Jolowicz, supra note 12 at 493; Kunkel, supra note 4 at 169-70; Leage, supra note 8 at 54; J.A.C. Thomas, Textbook of Roman Law (Amsterdam and Oxford: North-Holland Publishing Company, 1976) p. 58. 
excerpts were compiled into the books of the Digest. He said that each committee had two commissioners and a number of other personnel (barristers) attached to it, and he even offered a theory to identify which scholar was on which committee and what books each read. ${ }^{49}$

Each scholar was assigned particular books to read and excerpt. Honoré postulated that at the initial stage of excerpting, the two commissioners in each committee read and excerpted in groups of material, dividing each group into equal lots between them. The junior member handed his excerpts from each lot to the senior member who would file and distribute them in titles. If the senior member received them before completing work on his own lot, he might intersperse the excerpts of the junior member with his own. ${ }^{50}$ Honore suggests that each excerpt was on a separate piece of papyrus and they were stacked on top of one another, so the mass for a given title consisted of a pile of fragments with the first text on the bottom and the last text on the top as it was added.51 The excerpts from all the committees on each title were stacked together, and all the titles in a book were given to a committee to edit. Each committee edited about a third of the books-Honore believed that the work was done in alternative series, e.g. the Sabinian Committee edited books 1,4,7,10 etc. ${ }^{52}$ When this task was completed, the commission sat together to review the entire work as a whole. 53

The misfiling of fragments 6 and 7 began in the initial excerpting process when two committees filed material dealing with the same subject matter under different titles. The books the Sabinian Committee read and excerpted dealt with the actio furti a.n.c.s. and not with any other actions against the nautae, caupones and stabularii. The Sabinian Committee put the fragment on the actio furti a.n.c.s. in the Theft title, D.47.5.54 The Edictal Committee read and excerpted fragments which dealt with a variety of actions against the nautae, caupones and

49. Honoré, Tribonian, supra note 48 at 146-86. Honoré's theory on subdividing the readings was attacked in Douglas J. Osler, "The Compilation of Justinian's Digest," 102 Zeitschrift der Savigny-Stiftung fur Rechtsgeschichte, Romanistche Abteilung 129. 84 (1985). His theory on the identity of the committee members was criticized in David Pugsley, "Some Reflections on the Completion of Justinian's Digest," 19 Irish Jurist 350 (1984).

50. Honoré, Tribonian, supra note 48 at 156.

51. Id. at 175-76.

52. Id. at 180 .

53. Id. at $185-86$.

54. If Honoré is correct, Tribonian himself read and excerpted Ulpian, Edict books 28 and 38 as well as Gaius, Golden Words, book 3 which either are the source of the double penalty discussion [Ulpian book 38 in D.47.5] or refer to liability for seamen's wrongs as in the section on exercitores [Ulpian book 28 in D.14.1.1] or comparison to an item falling from an upper story [Gaius book 3 in D.44.7.5.6]. Honoré, Tribonian, supra note 48 at $258,261$. 
stabularii-the actio de recepto, the actio damni a.n.c.s. and the actio furti a.n.c.s. - and it filed them all together in the Restoration title, D.4.9. The Edictal Committee's decision to file all the references to actions against the ships' masters, innkeepers and stablekeepers under the same title followed from its methodology and the particular content of the passages excerpted.

If Honore is correct, Theophilus, the senior member of the Edictal Committee, excerpted the first five fragments of title 9 of book 4, the passages dealing with the actio de recepto. They were excerpted from three books which dealt generally with what this paper has called the restitutionary recovery. 55

Several fragments on the actio de recepto which Theophilus excerpted mentioned theft, but they were not concerned with the actio furti a.n.c.s. ${ }^{56}$ Shipwreck was an exception to liability under the actio de recepto, ${ }^{57}$ and theft was the likely explanation for goods lost aboard ship in any other way. The person liable for safekeeping was liable under the actio de recepto for stolen goods even if no one could identify the thief. The last paragraph of fragment three discussed the relationship between the praetorian action on the actio de recepto and the action for theft. 58 As fragment four, Theophilus added a section from Paul arguing that the nauta should be able to sue the perpetrator for theft because the nauta bore the risk. Paul then stated that the risk included

55. Ulpian, Edict, book 14; Gaius, Provincial Edict, book 5; and Paul, Edict, book 13. It appears that these texts, like the Digest, followed the order of the Perpetual Edict which treated matters referred to arbitration immediately before the actio de recepto. Ulpian's book 13 dealt with the arbiter and enforcement of his decree, so discussion of the receptum in book 14 follows that. Gaius book 5 dealt heavily with the arbiter as did Paul book 13.

56. It has been suggested that D.4.9.4 and 5 deal with the Furtum and damnum and not receptum. Huvelin, supra note 27 at 139. But Paul in fragment 4 refers to the risk borne by the nauta who can then bring the actio furti against the thief, and D. 47.5.1.4 makes clear that the nauta has this action if he has undertaken to restore the goods-i.e. he is liable for receptum. Fragment 5 citing Gaius discusses liability for safekeeping. Although it states that what is said of theft applies to property damage, the fragment centers on persons who agree to receive something on the understanding that it will be safe, a characteristic of the receptum. It seems likely that Gaius was discussing what liability existed under the receptum after the exception taken by Labeo for acts of God and piracy-it was for custodia just like persons who are paid for the safekeeping of goods. That meant the nauta was liable if the goods were stolen or damaged. In this sense, the passage is not referring to the actio furti for double damages, but simply to the liability under the receptum if the goods are stolen. See Feenstra, "Deux textes de Gaius sur la responsabilité contractuelle: D. 19.2.40 et D. 4.9.5," Droits de L'Antiquité et Sociologie Juridique: Mélanges Henri Lévy-Bruhl pp. 105, 116 (Paris: Sirey, 1959) [Publications de l'Institut de Droit Romain de l'Université de Paris, No. 27].

57. D.4.9.3.1.

58. "Lastly, it must be seen whether both a praetorian action on account of goods received and an action for theft can be brought in relation to the same matter. And Pomponius is doubtful. But the better opinion is that either by application to the judge or the defense of fraud, he ought to be restricted to one or other of them." D.4.9.3.5. 
liability for accompanying baggage for which no separate fee was paid. ${ }^{59}$ An excerpt from Gaius followed as fragment five, noting that the fees paid ships' masters, innkeepers or stablekeepers are not for safekeeping, but the liability for custodia still exists. That liability is not only for theft but also damage to the goods. The context of Gaius is a discussion of the obligation of safekeeping, so the reference to theft in this passage is not a reference to the legal action for theft (actio furti) but to the stealing itself. 60

The junior member of the Edictal Committee excerpted the other passages in 4.9 from Paul, Edict, book 22 and Ulpian, Edict, book 18. Those books dealt with the lex Aquilia. They discussed damages caused by slaves and quite naturally included a discussion of the action against nautae, caupones and stabularii for damaging property-the actio damni a.n.c.s. The junior committee member marked all the sections in these books of Paul and Ulpian that touched on the nautae and caupones and submitted them together to the senior member.

If we assume that the Digest rubrics were tentatively agreed upon before the reading commenced, the senior member had no separate title under which to file material dealing with the actio damni a.n.c.s. Theophilus could place the excerpts of his junior either in the title on actio de recepto which he was then working on or in the title on the actio furti a.n.c.s. whose contents he had not yet seen. The excerpts contained material on the furtum a.n.c.s. as well as the damnum a.n.c.s., but they did not come from a book on the furtum a.n.c.s.

The excerpts from Paul dealt inter alia with two issues Theophilus had just excerpted from the actio de recepto-whether recovery for stolen or damaged property was available when no fee was paid for safekeeping and what was the relationship of the action against the thief to the actions against the nautae. ${ }^{61}$ This led the senior member

59. "PAUL, Edict, book 13: Again, the action for theft is available to the "seaman" himself since he bears the risk, unless he should himself steal and afterward the property is stolen from him, or, in the case where another has stolen, the "seaman" himself is not solvent. 1. If a seaman receives the property of a seaman, a stablekeeper that of a stablekeeper and an innkeeper that of an innkeeper, he will still be liable. 2. Vivianus said that this edict also related to things which are brought in after the merchandise has been placed on board and the contract of carriage made, although no freight for them is due, such as clothing and daily provisions, because these things are themselves accessories to the contract for the carriage of the other things." D.4.9.4.

60. "GAIUS, Provincial Edict, book 5: The seaman, innkeeper, and stablekeeper. receive a reward not on account of the safekeeping of the goods, but the seaman so that he may transport passengers, the innkeeper that he permit travelers to stay in the inn, the stablekeeper that he allow beasts to be stabled with him; and yet they are liable on account of safekeeping. For the fuller and tailor receive a fee not on account of safekeeping, but for the exercise of their skill; and yet they are liable under the action for letting on account of safekeeping. 1. Whatever we have said about theft ought also to be understood about damage to property. For there ought to be no doubt that one who agrees to receive something on the understanding that it will be safe is held to undertake to keep it not only from being stolen but also from being damaged." D.4.9.5.

61. It included a discussion of the peculiar position of the slave hired out to a ship's master who stole or damaged his owner's property or who was injured by another, 
to put the passage from Paul, Edict book 22 together with his own excerpts on the actio de recepto. He knew that the passages on liability for travelers were not inconsistent because they referred to different types of liability, having drawn them from different locations, but there was no transitional defining phrase to point this out. The passage from Ulpian's book 18 was added as D.4.9.7 because it elaborated on issues discussed in 4.9.6. It is also possible that the provisions on waiver from D.4.9.7pr were understood to apply to the actio de recepto and that encouraged placement of the whole section in the actio de recepto.

The explanation that each subcommittee placed only the excerpts they read in a single title is not complete, however. All the commissioners would have known that two separate edicts existed-and the Sabinian Committee read and excerpted several paragraphs on the nauta's ability to sue the thief because the nauta was liable under the actio de recepto.62 Honore believed the Sabinian Committee under Tribonian was responsible for editing the excerpts in book 4 while the Edictal Committee under Theophilus was responsible for editing book 47. If that is correct, the repetition and the inconsistencies should have troubled them. Although there are some explanations for their failure to move the excerpts from Paul, book 22, and Ulpian, Edict, book 18 into Digest book 47 , ultimately the decision must be viewed as a mistake.

\section{The Lapse in Judgment}

One explanation is that the editors thought the actio damni a.n.c.s. more closely related to the actio de recepto than to the actio furti a.n.c.s. The promise of safekeeping implied in the actio de recepto included safety from all harm, whether loss or damage. ${ }^{63}$ Thus, the Restoration title, D.4.9, appropriately analyzes damage as just one type of loss

a discussion that might be relevant to either receptum or furtum. Only the innikeeper reference seems out of place.

62. D.47.2.14.17; D.47.5.1.4.

63. D.4.9.3.1; D.4.9.5.1. Another possible explanation for the placement would be that the actio furti a.n.c.s. was for double damages but the actio damni a.n.c.s. was for single damages like the actio de recepto. The person who damaged the goods would be liable to an action on the lex Aquilia, which was for single damages only unless the defendant denied liability. It would be extraordinary for the vicarious liability under the actio damni a.n.c.s. to exceed the liability of the perpetrator.'

But D.4.9.7.1 says this actio in factum lies for double. The previous passage discusses an action for damnum. Citing this portion of the Digest, both Lenel and Huvelin agree that the actio damni a.n.c.s. is for double damages. Lenel, supra note 9 at 205 . Huvelin, supra note 27 at 129 . Although it might be argued that the text refers to the actio furti a.n.c.s. or to double damages for denying liability, it is a powerful support for Huvelin's description of the evolution of the actio damni a.n.c.s. if it was for double damages. They would make sense only as a wholesale transfer of the formula for the actio furti a.n.c.s. to the actio damni a.n.c.s. 
whereas an action for theft of goods is distinct from an action for damages to goods.

Further, the editors may have believed that the prefatory words of each of the excerpted fragments also applied to the actio de recepto even though they were originally stated with respect to the actio damni a.n.c.s. and the actio furti a.n.c.s. Fragment 6 begins with the issue of liability for the goods of the person who has obtained lodging or passage gratuitously. It follows logically from the discussion in fragment 5 on the absence of separate payment for the luggage of travelers and passengers, and demonstrates that liability is not affected by whether the services are free or must be paid for. Fragment 6 continues with a hypothetical involving one person's slave who is employed by another on a ship or inn. The liability of the employer to the owner may have been the same for both the actio de recepto and the actio furti a.n.c.s. 64

Fragment 7 begins with references to the liability of ships' masters for the acts of their sailors, but then turns to the potential waiver by passengers of their rights against ships' masters. Waiver does not seem appropriate for the actio furti a.n.c.s. since it is based on the praetor's edict and the alleged fault of ships' masters in selection of the crew and not on the contract.65 If it were applied to the actio de recepto, however, it would make sense and buttress the argument that strict liability under the actio de recepto was contractual. ${ }^{66}$ Further, there is some joint application to the subsequent discussion of the liability of ships' masters for damage to the crew. ${ }^{67}$

64. The employer is liable to the owner for loss of goods, even if the owner's slave stole them. D.4.9.6.1. The employer may not be liable to the owner if the slave was injured by someone else who can be held liable independently. D.4.9.6.2. This could apply to the actio de recepto if the slave as employee is not considered property accepted for safekeeping. D.4.9.6.3 discusses the liability of the innkeeper for the actio furti a.n.c.s., but the limitation on the victim to either a suit against the perpetrator or against the operator in D.4.9.6.4 applies to the actio de recepto as well. D.4.9.3.1.

65. D.44.7.5.6. Note that the liability waiver only occurs if it is waived by a passenger who would be capable of watching the property. It does not apply to shipments of goods unaccompanied by owners or their representatives. Given the harshness of imposing double damages in a case of vicarious liability, it is not unreasonable to permit a waiver despite its exceptional nature.

66. The sentence on waiver was probably an interpolation. It states that if there is a waiver, the ship's master is not sued, i.e. there is no action. Thus, the following sentence, which begins "This action," refers to an action previously discussed and the sentence on waiver of liability appears to interrupt the natural grammatical progression. Waiver is an example of a situation for which the ship's master bears no liability, so the comment does relate to the prior statement that the ship's master bears no liability for the behavior of sailors off the ship. That explains its insertion, but it could have been wrenched from a different context where it referred originally to the actio de recepto.

67. The ship's master is unlikely to have guaranteed safekeeping to the crew member unless the individual is also shipping goods or working his passage. Thus, to whom a ship's master is liable may be alike for the actio de recepto and the actio furti a.n.c.s. D.4.9.7.2. 
These explanations for the placement of fragments 6 and 7 in the Restoration title are plausible, but the close relationship between the actio damni a.n.c.s. and the actio furti a.n.c.s. should have prevailed as an organizing principle. The references to the actio damni a.n.c.s. in the fragments are intertwined with references to the actio furti a.n.c.s. and therefore should have been placed in the title dealing with that action. Unlike the actio de recepto, the actio damni a.n.c.s. and the actio furti a.n.c.s. apply only when the loss or injury is inflicted by the operator or his employees. Although both the actio de recepto and the actio damni a.n.c.s. lie for damage to goods, they are otherwise quite distinct. In short, the commissioners made a mistake.

Despite the inappropriate placement of the fragments, the evidence is strong that there were at least two separate actions with different characteristics that coexisted in Justinian's era to respond to problems of theft, damage and loss in inns, stables and aboard ships-the vicarious liability of the actio furti a.n.c.s. with its double damages and the strict liability of the actio de recepto.

\section{The Origin and Development of the Explanations for the Actions}

The inconsistencies in the scope of liability and the measure of damages are easily resolved by the conclusion that there were two separate actions against nautae, caupones et stabularii. The explanation for the inadequacy of the Digest's justifications for those actions is more controversial. The statement in the innkeeper's duty paragraph that innkeepers chose long term residents but cannot refuse persons making a journey is probably a post-classical interpolation impelled by the desire to attribute fault. The contradiction in the operator's choice paragraph which states that nautae, innkeepers, and stablekeepers can choose whether to receive anyone is a phrase that lost its original meaning when the underlying law changed. An examination of the history of the actio furti a.n.c.s. and the actio de recepto reveals the real reasons behind their separate development and how the mistaken reasons became part of the Digest.

\section{A. The Obligation to Take Travelers-The Evolution of the Explanation for the Double Penalty of the Actio Furti A.N.C.S.}

The actio furti a.n.c.s. grew out of the actio furti (or action of theft). In the first century B.C. Servius Sulpicius Rufus responded to a case in which several persons had poured their grain together in a ship. The ship's master returned the grain to one of them and later the ship foundered and the rest of the grain was lost. Servius said that if the grain had been separately enclosed so as to belong to identifiable individuals separately, interchange would not be permitted 
and the owners of the grain could sue the ship's master for theft. ${ }^{68}$ The inappropriate mixing and misdelivery of the grain would probably be done by the crew at the behest of the captain, acting within the scope of his authority. Actio Furti for this behavior may have been the first step in making the operator of the ship liable for any theft committed by the crew.

The Digest justifies the actio furti a.n.c.s. by the fault of the master in "using the services of bad men" 69 or because he "himself has made use of their services at his risk" for employing such persons." ${ }^{\prime}$ But making a bad choice of employees does not create double liability on employers in other businesses for thefts by their employees. Thus, the fault or culpa notion seems an afterthought rather than the original reason for the action.

Huvelin contended that the actio furti a.n.c.s. was the natural result of merchants bringing the actio furti where the goods they loaded on ship were not delivered. If nothing had happened to the vessel, the explanation must be theft. Although the thief's identity might not be known, it was likely to be a member of the crew. Huvelin thought the praetor may have decided the operator of the business should be liable anyway. ${ }^{72}$ But the Digest provisions on the actio furti a.n.c.s. allow recovery only where the plaintiff proves that the theft was committed by a member of the crew. ${ }^{73}$

In extending the actio furti to liability of the nautae and others, the praetor was probably influenced by the likelihood of collusion between the employee and the employer. ${ }^{74}$ Fear of collusion was an

68. D.19.2.31.

69. D.44.7.5.6.

70. D.4.9.7pr.

71. D.4.9.7.4.

72. Huvelin, supra note 27 at 120.

73. D.47.5.1.pr,6.

74. Sargenti suggests the extension of the furtum was connected to the principle behind noxal liability. Manlio Sargenti, "Osservazioni sulla responsabilità dell'exercitor navis in diretto romano," Studi in memoria di Emilio Albertario, I (Milano: Giuffre, 1953) pp. 553, 579-80.

A property owner could not recover damages for theft from a slave because all goods obtained by a slave belong to the slave's master. "Slaves are in the power of their owners." Gaius, supra note 5 at 45 [I:52]. A slave also might be permitted by the master to have a "peculium" for his own use which would be subject to suit. However, the owner could sue the slave's master. Under the ancient principle of "noxal liability," the master had the choice of paying the amount owed by the slave or of turning the slave over to the injured party. "Noxal actions lie when sons in power and slaves commit a delict, for instance, theft or contempt. These actions allow the father or owner either to pay the damages as assessed in money, or to make noxal surrender. . . Some noxal actions were established by statute, some by the Edict of the Praetor. Statutory instances are the action of theft under the Twelve Tables and for wrongful loss under the Aquilian Act." Id. at 463-64 [II:75-76]. See also Leage, supra note 8 at 69. This rule of "noxal liability" also applied to harm done by animals. 
explanation offered for the actio de recepto. ${ }^{75}$ Collusion with employees was a greater problem in inns and stables, but it may have applied to ships as well. ${ }^{76}$ The possibility of collusion also existed for the long term lodger, whereas the casual relationship formed for the purpose of a single night's rest or passage on the boat would not be as likely to offer opportunities for conspiring against the other customers.

Although fear of collusion underlay both the actio furti a.n.c.s. and the strict liability of the actio de recepto, that concern alone could not explain the existence of two actions or the penalty in the actio furti a.n.c.s.. The true explanation lay in the different paths by which the actions developed: the actio furti a.n.c.s. evolved out of the penal actio furti while the actio de recepto came from an express promise. But historical explanations for doctrine were not appealing to Roman jurists, who were concerned only with current doctrine. ${ }^{77}$

The classical jurists usually expounded on rules without giving the reasons behind them, but post-classical writers influenced by the Greeks

In republican Rome, this principle of noxal liability applied to the members of the family as well because all wealth was controlled by the paterfamilias. The paterfamilias could either pay compensation for wrongs done by family members, or surrender the offending member to the control of the injured person. In practice, of course, noxal surrender of family members would be unusual, and the paterfamilias would most likely pay the family debt. The noxal surrender of women swiftly disappeared on moral grounds. Noxal surrender of sons vanished more slowly, probably in line with the growth of sons' rights to some independent means "peculium." The extent of the "peculium" was greatly enlarged for soldiers during the many periods of warfare of the principate and the empire. Thus noxal liability for sons had essentially disappeared by the time of Justinian. Leage, supra at 423-26. This basis for liability did not apply to free employees who were personally responsible for their own wrongdoing. Nevertheless, it laid the foundation for finding persons liable for the wrongs done by members of their household.

The employee of an innkeeper, stablekeeper or ship's master may have stayed on the premises where people and animals remained over the evenings. In this sense they were closer to members of the operator's household than in other businesses. Further, the long term lodger became identified with the household of the innkeeper because the innkeeper could exclude him. The overnight sojourner had no such identification because he was only a very temporary resident. With respect to these peculiar households, the traveler was at a special risk because he or she did not know the character of the operator or his employees.

The growth of the peculium led to the end of noxal liability for family members. Only noxal liability for slaves remained. By Justinian's era, an explanation which distinguished liability between lodgers and travelers in terms of membership in the household no longer seemed relevant because the paterfamilias was not liable for household members.

75. D.4.9.1.1 and D.4.9.3.1. The explanation is usually considered an interpolation.

76. Innkeepers generally had a bad reputation. See Kleberg, supra note 19 at 6 , 27-28, 74-97; Firebaugh, supra note 19 at 124, 135, 245. See also G. Hermansen, "Roman Inns and the Law: The Inns of Ostia," in Polis and Imperium: Studies in Honour of Edward Togo Salmon (J.A.S. Evans, ed.; Toronto: Hakkert, 1974) pp. 167-70.

77. Gaius is exceptional in discussing the evolution of Roman law. See Fritz Schulz, Principles of Roman Law (trans. Marguerite Wolff; Oxford: Clarendon Press, 1936) pp. $99,102-05$. 
began to offer reasons for legal rules, interpolating them in the classical texts. ${ }^{78}$ They wanted an explanation to justify the law now, and an accident of history would not do. To justify infliction of a penalty, ordinarily the defendant must be at fault. Here there was no fault, unless it was the master's bad judgment in choosing the employee. That then became the justification offered. But fault in choice-culpa in eligendo-does not work as well for the distinction between lodger and traveler unless it can be said that the lodger is "chosen" in a manner different from the traveler. And indeed that is exactly what the Digest says in the innkeeper's duty paragraph. Thus, a distinction founded in a prophylactic policy to prevent collusion in theft led to a post hoc rationalization of fault which required a difference between lodgers and travelers in terms of the innkeeper's ability to choose whether to accept them.

\section{B. The Power to Choose Customers-The Evolution of the Justification for the Actio de Recepto}

The reference to the power to choose customers in the operator's choice paragraph originated in a different context where the language served as effective justification for strict liability. The Latin phrase initially referred to the operator's decision to expressly promise to keep the goods of passengers or guests safe. Enforcing such an obligation was not too harsh, for the promisors voluntarily undertook it. Gradually, such a promise came to be implied in the contract for carriage or lodging, and it could not be avoided unless the innkeeper or ship's master expressly disclaimed it. The shift in the burden of expression was not perceived to alter the suit and did not affect the justification. When Justinian's compilers came to abridge the writings on the actio de recepto, they found the reference to choice with respect to making a promise; but now that the promise was implicit, the same words meant choice with respect to accepting the customer. Since ships' masters had such a choice, the compilers left the explanatory passage intact although its meaning had changed.

\section{Original express promise in shipping contract to be responsible for loss or damage}

The origin of the actio de recepto was an express guarantee by the person managing the boat to keep the goods safe. ${ }^{79}$ The origin

78. Id. at $98-100$.

79. There is general agreement that the actio furti a.n.c.s. preceded the receptum. Sargenti, supra note 74 at 553-80; J.C. Van Oven, "Actio Recepto et Actio Locati," 24 Tijdschrift voor Rechtsgeschiedenis 137. Cf. Francisco De Robertis, Receptum Nautarum (1952). If strict liability existed pursuant to the actio de recepto, there would 
is reflected in the edict which provides for an action against the nauta, caupones et stabularii "in respect of what they have received and undertaken to keep safe." ${ }^{0} 0$ The language suggests an expresss undertaking to keep the goods safe.

Further, in discussing the option of the owner of stolen property to sue either the thief in a civil action or the operator of the ship, stable or inn in a praetorian action, Ulpian adds, "But if the innkeeper or the ship's master has guaranteed the safety of the goods, it is he and not the owner of the stolen thing who will have the civil action of theft because, by his guarantee, he incurs the risk of safekeeping." 81 The passage suggests that the assurance of safekeeping must be express, because it departs from the norm stated in the prior sentence in which the owner of the goods would have the action for theft. ${ }^{82}$ The express nature of the promise to keep goods safe is also supported by the evidence from papyrus records of shipping transactions in Egypt. They reveal during the Roman era of Egypt that shippers made an express promise to keep the goods safe. ${ }^{83}$

have been no need for the actio furti a.n.c.s., which provides liability in more limited circumstances. Absolute liability should be a sufficient deterrent to negligence or misconduct by the nautae or caupones without any additional spur of double damages. If the actio furti a.n.c.s. came first, however, there would have been a need to create a more extensive civil action (receptum) to cover situations where the actio furti a.n.c.s. failed to apply. On the other hand, it might be argued that the express guarantee of the safety of goods came first; then an action (actio furti a.n.c.s.) that was available in the absence of the express statement; and finally a liability which collapsed the express guarantee and the general norm in receptum.

80. D.4.9.1pr. The person who lost goods in an inn or aboard a ship could also sue under the civil law for negligence in the leasing or hiring or for fraud by a bailee in deposit.

81. D.47.5.1.4.

82. If the holder paid the owner for the loss, the owner had to cede his actions against the wrongdoer to the holder. For example, "If a fuller or a clothes-mender loses clothing and then gives satisfaction to the [clothing's] owner on this score, the owner must cede the vindicatio and the condictio for it." D.19.2.25.8. If the property was stolen from a holder who was liable to the owner for custodia, which includes liability in the case of third party theft, the holder could maintain the action in furtum. The owner then was barred unless the holder was insolvent. Thus, the holder could obtain multiple damages while the owner could get from him only the value of the thing stolen. There was, however, only a remote possibility that the holder would actually profit from this rule, because of the uncertainty of catching the thief and the probability that, if caught, the thief would not even be able to pay the value of the stolen goods. Leage, supra note 8 at 398-407. At the same time, ships' masters might worry that a thieving crew member would leave town if the legal process was long delayed. Thus, ships' masters might have been influenced to make promises of strict liability in order to be able to bring the actio furti against their crew members immediately, rather than waiting until they lost a suit under the actio furti a.n.c.s. before being able to obtain a right to sue the thief.

83. "The meaning of the clause is that nauta takes the responsibility for every casus including vis maior." Raphael Taubenschlag, The Law of Greco-Roman Egypt in the Light of the Papyri: 332 B.C.-640 A.D. (New York: Herald Square Press, 1944, p. 288). 
The shipping arrangements might not be made in person, and that might make it difficult to enter into an enforceable stipulatio. ${ }^{84}$ Under the agreement of hire, locati-conducti, ships' masters were liable for loss caused by their fault. ${ }^{85}$ If the whole ship was hired, the merchant could bring an action for his lost goods on the hire, ex conducto. If the nauta was hired to transport the goods, the merchant could sue on the act of letting, ex locato.86 When it was unclear whether the owner of goods "hired the ship or leased out the transporting of the cargo" as a job, the praetor would give an actio in factum. ${ }^{87}$ But these actions were based on fault. Liability without fault required a promise of safekeeping. If that promise was in addition to the agreement of carriage, it might not have fit the previously existing categories of enforceable promises. That would be sufficient to lead the praetor to announce in an edict that such promises were enforceable.

\section{Original explanation refers to discretion to promise}

The operator's choice paragraph states that strict liability on the nauta and others was not too harsh because "nam est in ipsorum arbitrio, ne quem recipiant" (emphasis supplied), which has been translated as "it is in their own discretion whether to receive anyone." But "recipere" is ambiguous. It may refer to making a promise or taking responsibility rather than simply receiving the person or the goods.88 If given the meaning of "promise," the statement is an excellent rebuttal to criticism that strict liability is too harsh. If ships' masters were not willing to undertake liability for loss that they did not cause, they did not have to. "It is in their own discretion whether to promise anyone." That is probably the original meaning of the phrase.

\section{Express promise becomes naturale negotii an implied term of the} agreement by the agreement by the time of Justinian if not before

There is some controversy over whether innkeepers or nautae were liable only if they expressly promised to keep the goods safe or whether the promise was implicit. ${ }^{89}$ Most commentators agree that the

84. Stipulatio was a formal method of creating a unilateral obligation by means of an oral question, setting out the terms of the obligation, and an immediate oral answer acceding to those terms.

85. D.19.2.13.1,2; D.4.9.3.1.

86. D.4.9.3.1.

87. D.19.5.1.

88. Huvelin, supra note 27 at 137; J.B.C. Stephen, "The Water-Carrier and His Responsibility," The Law Quarterly Review 46:116, 119 (1896); Van Oven, "Actio de Recepto," supra note 79 at $137,149$.

89. Crook, supra note 27 at 226. 
edict as stated in the Digest imposed an agreement to keep goods safe in the absence of any disclaimer..$^{90}$

First, the ship's master is said to accept goods and undertake that they will be safe "even if they have not been handed over. . . . [H]e receives for safekeeping all the goods which have been brought onto the ship." Although this passage could be read as a guide to interpreting the extent of an express undertaking, the statement seems more likely to assume that allowing goods on board involves such an undertaking without an express statement.

Second, the Digest says liability for loss extends to goods which were not even mentioned in the contract:

this edict also related to things which are brought in after the merchandise has been placed on board and the contract of carriage made, although no freight for them is due, such as clothing and daily provisions, because these things are themselves accessories to the contract for the carriage of the other things.92

An express undertaking to keep them safe would be unlikely.

Third, liability does not depend on an exchange of value for an undertaking to keep goods safe.

The seaman, innkeeper, and stablekeeper receive a reward not on account of the safekeeping of the goods, but the seaman so that he may transport passengers, the innkeeper that he permit travelers to stay in the inn, the stablekeeper that he allow beasts to be stabled with him; and yet they are liable on account of safekeeping. ${ }^{93}$

This suggests that the liability extends to all goods with no specific transaction or promise to keep them safely.

90. Leage says the undertaking was implied upon the promisee's entry, but the relationship between the liability on the undertaking and the liability for tort was uncertain. Leage, supra note 8 at 381, 422. Mackeldey says the ship's master or innkeeper who receives the things of a traveler in his ship or inn contracts a strict obligation, and may be sued in an action in factum de recepto. Mackeldey, supra note 27 at 361 . "Receptum nautae, cauponis, stabularii was an undertaking required by the edict of ships' masters, innkeepers and livery stable-owners that their clients' goods would be safe (res salvas fore) while on their vessel or premises." The Institutes of Justinian (trans. J.A.C. Thomas; Amsterdam and Oxford: North-Holland Publishing Company, 1975) p. 249, 280-82. See also Max Radin, Handbook of Roman Law (St. Paul: West Publishing Co., 1927) p. 254-55. Leon-Robert Ménager, "Naulum' et Receptum Rem Salvum Fore' Contribution a L'Etude de la Responsabilite Contractuelle dans les Transports Maritimes, en Droit Romain," Revue Historique Du Droit Français et Etranger 37:177-213; 385-411 (1960).

91. D.4.9.1.8.

92. D.4.9.4.2. This statement of Vivianus quoted by Paul is also found in a slightly different form in a fragment of Ulpian. D.4.9.1.6. J.A. Crook said that the actio de recepto and the actio furti a.n.c.s. applied only to baggage and not to the carriage of freight in general. Crook, supra note 27 at 226. But the quotes from Vivianus indicate that the actio de recepto applied to merchandise as well as baggage. Further, other passages on the actio de recepto specify liability for all (omnium) goods (D.4.9.1.8), and discuss merchandise that had been pledged as security (D.4.9.1.7) and is therefore unlikely to be simply baggage.

93. D.4.9.5pr. 
Fourth, the passage continues: "For the fuller and tailor receive a fee not on account of safekeeping, but for the exercise of their skill; and yet they are liable under the action for letting on account of safekeeping." A fuller is a person who cleans and thickens cloth. The liability of a fuller under the contract includes liability for theft by third parties. ${ }^{94}$ The analogy to the fuller and the tailor are to occupations where liability is not based on an express undertaking, but on an implied understanding arising out of the job. ${ }^{95}$ Thus, the analogy suggests that the ship's master, innkeeper or stablekeeper were likewise liable without an express promise.

Fifth, the rationale offered for liability is not that it accords with the promise of the ship's master or the innkeeper, but that it is an important protection against collusion with thieves. This policy makes more sense applied to all transactions rather than just those where a special promise has been made.

Sixth, the provision that the person in charge of the ship will not be sued if the passengers accept his declaration that he is not liable indicates that liability was implicit unless expressly repudiated. 96 The disclaimer might be an effective warning to customers that it was risky to deal with that operator.

Finally, evidence that the actio de recepto had become an implicit term of the contract of transport rather than needing an express agreement is found in the papyri. The express clauses of the third and

94. "A fuller lost your clothing; there is a third party from whom you may claim them, but you do not choose to reclaim them. Despite this you sue the fuller on the lease. But [Labeo thinks that] the judge would determine whether you can better proceed against the thief and obtain your property from him, at the fuller's expense, of course; but if he observes that this is impossible for you, then he will make the fuller pay you but will force you to provide him with your actions." D.19.2.60.2.

J.A.C. Thomas, "Furtum and Locatio Conductio," 11 Irish Jurist (New Series) 170 (1976) attacked this passage as a corruption. He argued that liability of the fuller is independent of the discovery of the wrongdoer and that no official would deprive an individual of an action under these circumstances.

The fuller's liability is a civil action on the agreement-locatio operis. Although there was a similar action against the nauta, it did not include liability for theft by underlings. Thus, Pomponius expressed surprise at the existence of the praetorian action against the innkeeper or ship's master, but noted that liability in hire was for fault while the action against the innkeeper or ship's master lay without regard to fault. D.4.9.3.1.

95. "If Ude's theory could be accepted, according to which 'recipere' only means to take over responsibility and the 'salvum fore recipere' of the edict indicates nothing but a praetorian pact, difficulties would vanish. But 'recipere' here signifies to receive the person rather than the higher liability in respect of him or his property." Stephen, supra note 88 at 136.

96. D.4.9.7pr. It may be argued, however, that this waiver applies only to waiver of the liability under the actio furti where double damages lie for the behavior of the crew of a ship or the staff of an inn. 
fourth centuries are no longer found in the shipping documents of the fifth and sixth centuries. 97

The movement from express to implicit undertaking was eased by a reduction in the liability of the ships' masters. Labeo is said to have made an exception in the actio de recepto for shipwreck and piracy. But that left the ships' masters liable for something very close to custodia, which was the liability of bailees for hire. While it would be harsh to impose liability on ships' masters for force majeure without an express agreement, it was not unreasonable to imply an agreement to incur the common lesser obligation.

\section{Explanation now refers to ability to reject passengers and freight}

To recapitulate: early texts said that the strict liability of the actio de recepto was not too harsh because it did not lie unless the ship's master decided to promise expressly to keep goods safely (ne quem recipiant). Over time, this guarantee of safekeeping became an implicit element of the shipping contract. It attached whenever the goods were received on board. The new legal context affected the interpretation of the inherently ambiguous "recipere." It changed its meaning from "taking responsibility for" in classical times to "receiving" in Justinian's era. ${ }^{98}$ Thus, the translation of ne quem recipiant in the operator's choice paragraph as "whether to receive anyone" is correct. Ships' masters did have the power to refuse to carry goods or persons, so it was a true statement of law, ${ }^{99}$ but it no longer made much sense as an explanation.

The evolution from express promise to implicit term left its traces in Digest passages which distinguished between ships' masters that had undertaken to keep the goods safely and those who had not. After the undertaking became implicit, the ships' masters could expressly repudiate it. It was still important to discuss the effect of choosing

97. Taubenschlag, supra note 83 at 287-89.

98. "In classic law, the receptum was the declaration of the clear and explict will of the captain of the boat, that he had received the goods and that he was agreeing to deliver them salvas, however in the law of Justinian recipere signified simply accepting the goods in the boat (illatio in navem), or even at dockside (in litore), without an express clause of guaranty. That was a consequence of a new juridical regime, i.e. of the changed notion of receptum which becomes a naturale negotii. This change manifested itself even in the rubrica of the title D.4.9, for instead of the edict's expression on the receptum, i.e. "quod cuisque salvum fore receperint," one reads there "nautae, caupones, stabularii ut recepta restituant." Thus the words salvum fore have disappeared." J.C. Van Oven, Book Review of De Robertis, Receptum nautarum, 2 Revue Internationale des Droits de l'Antiquité (3d Series) 423, 427 (1956) [translated from the French].

99. The Digest offers other passages that support the ship's master's ability to choose whether to take passengers. For example, the owner is not liable if the captain violates instructions and takes on passengers when hired only to take goods. D.14.1.1.12. There are no similar passages about innkeepers. 
whether to be bound by an undertaking to restore goods. The early texts treated the absence of a promise as the standard. Although they would have been phrased differently if written after the development of an implicit obligation, the early texts continued to be accurate statements. Thus, they were not altered by the compilers.

\section{The hypothesis of a separate edict governing the actions against the Innkeeper and Stablekeeper}

The praetor may have issued separate edicts for nautae and for caupones which were consolidated.100 The theory that there were originally separate edicts is supported by the language of the Digest. Sentences that begin with references to those who operate ships, inns or livery stables conclude with reference only to the ship. ${ }^{101}$ This suggests that the initial references to inns and livery stables were added to a statement on the liability of ships' masters. ${ }^{102}$

These arguments suggest that the language of choice in D.4.9.1pr, the operator's choice paragraph, originally applied only to ships' masters. ${ }^{103}$ But Justinian's scholars surely knew that adding "innkeepers and stablekeepers" to create a single edict in the first sentence of the chapter made the language of choice refer also to innkeepers. Indeed, scholars who propose the separate edict theory have argued that the

100. J.A.C. Thomas, "Carriage by Sea," 6 Revue Internationale de Droit de l'Antiquite (3d Series) 489 (1960). Van Oven argued that ships' masters were largely under a different juridical regime than innkeepers. The ship's master contracted for his carrier to be an active agent with respect to passengers and goods. He carried them from one place to another; so masters were conductores operis faciendi. The inn and the stable merely leased space to the customer and were locatio re, not locatio operis. Van Oven, Review, supra note 98 at 425 . But Van Oven has overstated the case. Thomas noted that sometimes the sea carriage was also merely a lease of space and also locatores rerum. Thomas, "Carriage by Sea," supra at 496. Further, there is some question whether lodging and stabling were considered purely as leased space, especially since connected services such as feeding the horse were likely to be involved.

101. D.47.5.1.pr; D.47.5.1.2.

102. Wherever a principle of general application is stated in D. 47.5 , the specific example always refers to shipping. The innkeeper is specifically discussed only at D. 47.5.6 where the liability rules differentiate between lodgers and overnight guests, a consideration inapplicable to ships' masters. Indeed, the reason given for imposing liability on the innkeeper for lodgers, i.e. that the innkeeper selects his permanent residents, applies to the ship's master who may choose his passengers; nevertheless, the ship's master is not liable under this chapter for the behavior of passengers. The impression created is that one author wrote on the edict for ships' masters, and someone else later added comments on innkeeper liability from another edict because the edicts shared a common trait of imposing vicarious liability.

103. If "innkeepers and stablekeepers" were inserted next to "ships' masters" in commentary that originally dealt with ships' masters, a phrase relating solely to ships' masters could erroneously be made to apply to both. Thus, one explanation for the apparent conflict in the passages on the duty to serve is that the ability to choose whom to serve described in D.4.9.1.1 referred only to the ships' master. 
operator's choice paragraph consists of sections taken from commentary on the edict on nautae combined with a section taken from commentary on caupones et stabularii. ${ }^{104}$ Thus, even if the theory of separate origins is true, the compilers intended that commentary applicable to one business be understood to refer to the others as well. ${ }^{105}$ Tribonian and his coworkers could see that the text stated that innkeepers had a choice whether to serve customers-and it is hard to understand why they would let it stand if they knew it to be false.

\section{The Obligation to Accept Customers}

Thus far, this article has explained the apparent conflict in the liability of ships' masters, innkeepers and stablekeepers for losses of their customers' property and the reasons for the weakness of the explanations offered. But that does not resolve the question whether there was an obligation in Justinian's era for innkeepers to serve the public.

\section{A. Theories to Reconcile Digest Language With a Duty to Serve}

A number of theories have been offered to show that the language in the Digest on the obligation to serve the public is not contradictory. Several theories insist that there was a duty to serve the public.

\section{1. "Recipere" Means Promise}

The prior discussion demonstrated that the text of the operator's choice paragraph could be read to say only that the operators of the specified businesses had discretion whether to promise to keep the goods safe. That reading eliminates any direct statement that innkeepers could decide whether to accept persons, and therefore it would be consistent with the proposition that the innkeepers had a duty to accept travelers.

This theory has several flaws. First, the promise to keep goods safe was implied and had to be specifically repudiated. Although the operator of the business could avoid being held for a promise, it is awkward to describe this as a choice of whether to make a promise

104. Van Oven, Review, supra note 98 at 425.

105. Under the theory of separate edicts, the historical development was: Originally, someone stated that enforcement of strict liability against nautae was not harsh because they can choose whether to undertake such responsibility. By the time of Ulpian, the undertaking was implicit in the agreement of carriage. Ulpian repeated the justification he had heard, but now it meant that nautae can choose whether to accept particular passengers-an accurate statement, but a weak explanation for the imposition of strict liability. The compilers then took this explanation and applied it to innkeepers in the process of uniting the receptum edicts. 
when the decision to make no promise requires an express statement of repudiation.

Second, recipere in the phrase ne quem recipiant is more likely to refer to receiving than to promising, for it is part of a sentence in which recipere is used to mean "receive" rather than "undertake responsibility." The remainder of the sentence refers to conspiracy of the operators with thieves against those whom they receive: "nisi hoc esset statutum, materia daretur cum furibus aduersus eos quos recipiunt coeundi"-_unless this provision were laid down, there would be given the means for conspiring with thieves against those whom they receive."106 The possibility of collusion with thieves exists whether the ship's master or innkeeper expressly undertook to keep goods safe or not. Thus the passage makes more sense if "recipere" refers to receiving persons and their goods rather than undertaking responsibility for them. ${ }^{107}$ But if "recipere" means "receive" throughout the sentence, then the passage states that the innkeeper or ship's master does not have to receive guests or passengers.

\section{Mistake in the Latin Text}

A second alternative is to interpret the right to refuse to receive anyone as a reference to the decision whether to get into the business at all. "The glossators, followed by Cujas, Pothier, and Gluck, read 'neminem recipere' instead of 'ne quem recipiant.' In other words, seacarriers must carry for all who applied to them, but no one need be a sea-carrier." 108 The suggestion neatly reconciles the conflicting passages on the obligation to serve the public by denying that the first passage deals with that obligation. It also is more consistent with the "innkeeper's duty" paragraph, D.47.5.1.6, that categorizes passengers with travelers as persons for whom the operator is not liable in the action for theft.

Nevertheless, there is insufficient evidence that the Latin text was altered. ${ }^{109}$ The existence of a choice on whether to enter a business is a weak basis for arguing that strict liability is not harsh. The better explanation is that the phrase in question initially referred to the discretion to make a promise; but if that explanation is correct, the

106. D.4.9.1.1. I Watson, supra note 2 at 160 .

107. If the ship's master undertook responsibility expressly for the goods of another, it would be extraordinary to let him off. Fear of collusion with thieves would be unnecessary to justify the receptum.

108. Stephen, supra note 88 at 136.

109. As discussed in part III, D.47.5.1 is not really inconsistent on liability for passenger's behavior, but simply refers to a different action. The only conflict in texts deals with the innkeeper's obligation. There is no indication in the Digest that a ship's master had an obligation to carry passengers. Thus, there is no greater reason to believe the text here was inaccurate than that the text in 47.5 on innkeepers was inaccurate or than that a mistake was made. 
Latin phrase would be ne quem and not the altered neminem. Furthermore, if the carrier was required to serve all applicants, it would be difficult for it to impose a waiver of liability. Yet the Digest makes it clear that the carrier had that power. ${ }^{110}$

\section{Innkeeper Choice Refers Only to Lodgers}

A third reading reconciles the conflict by positing that the operator's choice paragraph referred only to receiving lodgers. ${ }^{111}$ The distinction between lodgers and travelers is found in discussions of the actio furti or damni a.n.c.s. at D.47.5 and 4.9.6.3 where it is used as a rationale for distinguishing for whose acts the innkeeper is liable.112 But the operator's choice paragraph deals with the actio de recepto and the issue is not for whose acts but to which persons is the innkeeper liable. There is nothing in the text of D.4.9.1 to suggest that the discussion is limited to lodgers and that the innkeeper would not be liable for the losses of overnight guests. The rationale of fear of conspiracy to rob applies equally well or better to the fears of travelers rather than lodgers. In short, this theory had no good linguistic basis and is justified only by assuming that the distinction drawn in 47.5 is correct and that preserving it consistently must override all other considerations. The specific references to lodgers are appropriate for the actio furti or damni a.n.c.s., but the references in book 4 concerning the actio de recepto cover all customers.

\section{B. Reconciling Digest Language With the Right to Reject Travelers}

Several alternative readings lead to an interpretation of the innkeeper's duty paragraph, D.47.5.1.6, as a reference to the desirability

110. D.4.9.7pr. Perhaps a carrier could secure a liability waiver by lower prices, but the hypothesis of a different charge where there was a guarantee of safekeeping runs contrary to the tenor of passages stating that liability for goods attached even if the owner paid no fee for their carriage. D.4.9.4.2; D.4.9.5pr; D.4.9.6. But see LeonRobert Ménager, supra note 90 (citing D.20.4.6.1 for the proposition that merchants paid a higher price for the receptum, although that paragraph appears to refer to payments for exertions to save cargo threatened with loss rather than payments for a guarantee of safety).

111. "Guyet supposed the first passage referred to the persons "qui habitandi causa recipiuntur,' and the second to those 'qui hospitio recipiuntur.'" Stephen, supra note 88.

112. "The innkeeper is liable under the actio in factum on account of those who are living in the inn. However, this does not relate to one who is received as a passing guest, such as a traveler." But liability under the actio de recepto is specifically extended to the acts of travelers- "uiatorum" by Gaius at D.4.9.2. This contradiction in liability is normally explained by finding Paul's statement to be a reference to the actio furti a.n.c.s. and not to the actio de recepto. 
of taking in travelers and not to a legal obligation. ${ }^{113}$ First, the innkeeper might not know anything about the stranger who appeared suddenly at his door, and thus lacked information as a basis for choice. In this sense, he would not be able to choose the traveler as he chose lodgers. Second, the innkeeper could not refuse to give the traveler a room, because it would undermine his business if individuals could not rely upon getting accommodations there. Third, he is unable to refuse because the "road agent" needs shelter and the innkeeper is under a moral imperative to afford it. These readings show that the phrase does not require the conclusion that the innkeeper is legally obligated to accept travelers. Thus they support the proposition from the operator's choice paragraph, D.4.9.1, that there was no obligation under Roman law for innkeepers to serve the public. ${ }^{114}$

These attempts to interpret the phrase resolve the inconsistency in statements on the duty to serve the public, but they create their own problems. Innkeepers do know the identity of at least some recurring travelers and thus would be able to make an informed choice on accepting them. If occasional individuals were rejected, it might have only a marginal effect on business. Without an advance reservation, no one can rely on an inn being available rather than full. Thus, if an innkeeper has a legal right to refuse a traveler, it seems unrealistic to say that he cannot. Certainly "nec repellere potest iter agentes"-"he cannot refuse the traveler" appears to go beyond a moral obligation. Although it does not say he "may not" refuse the traveler, which would be most appropriate for a legal limitation, even lawyers sometimes use "can" in stating what the law allows and forbids.

\section{The Absence of Law}

Each of the foregoing explanations assumes that there was a rule of law with respect to the innkeeper's obligation to accept travelers. Yet the statement of the "rule" comes in the guise of premise for reasoning. There are no other passages in the Digest on the obligation of carriers to accept goods, though breach of such an obligation might be expected to be a delict. In fact, the issue would be very unlikely to arise. The

113. "But the opinion usually accepted is, that Roman innkeepers and sea-carriers were under no obligation to receive or carry for all who applied to them, and that the 'nec repellere potest iter agentes' merely signified that such a course would be detrimental from a business point of view." Stephen, supra note 88 at 136.

114. "At common law, the innkeeper was held to be exercising a public calling and under a duty to receive all guests against whom no reasonable objection could be made. That was not the case at Roman law. Innkeepers could freely select their guests as carriers could select the persons they wished to contract with. Indeed this choice is given as the reason for imposing a specially grave burden upon them." Radin, supra note 90 at 255 . 
innkeeper has every incentive to accept the traveler if he has room. A rejection would be upsetting, but it would not produce easily measured monetary damages that would provide incentive for suit. The slim likelihood of damages would not outweigh the disruption of travel plans which would result if the excluded person sought redress in court. 115

The lack of any authoritative determination of the innkeepers' responsibility to serve the public explains why the conflicting statements in different books of the Digest were not reconciled. Justinian's scholars working in different areas did not find any conflict with current law because there was no current law. The statements of law on the actio de recepto and the actio furti a.n.c.s. were accurate, and the assumption used in reasoning was an incidental remark of little importance.

If there was no edict, it is unlikely that anyone could sue for damages because they had been rejected from an inn. ${ }^{116}$ However, there may have been enough uncertainty in the edict which gave rise to the action for deliberate affronts (iniuria) to leave room for argument that the action was available for rejection from an inn. ${ }^{117}$ After all, if there was room at the inn, exclusion would signify a personal revulsion that could be seen as detrimental to an individual's reputation. Further, the action lay where "one is not allowed to use the public baths or to sit in a theater seat or to conduct business, to sit or converse in some other such place, or to use his own property."118 This form of iniuria dealt with third party interferences with conduct at a place where one has a right to be, but it suggests the broader principle that there were places from which people might not be barred without affront. It might be argued that this should apply to inns, although inns were not specifically discussed and the issue of its application had never arisen.

If the compilers had been forced to confront the issue, they probably would have found that innkeepers had no obligation to accept travelers. Exclusion from an inn is just not sufficiently close to accepted incidents of iniuria - the insult may not be public, the affront is based on inferences from behavior rather than specific slander, and legal recognition of exclusion as an insult would compel establishment of an involuntary

115. See Bruce Frier, Landlords and Tenants in Imperial Rome (Princeton: Princeton University Press, 1980) pp. 48-52 (noting reasons for not bringing suit, including smallness of sums involved where dispute is over short term rental).

116. It is possible, however, that municipal laws or innkeeper association by-laws may have regulated inns and required them to serve all comers.

117. See Crook, supra note 27 at 250-55 (discussing the development of iniuria from physical assault in the Twelve Tables through forcible entry on private premises under the lex Cornelia and libel and slander by a senatusconsultum to the broad and open language of the praetor's edict). The lex Cornelia did not allow suit because someone invaded another's temporary lodgings, but this principle dealt only with the trespass aspects of iniuria. D.47.10.5.5.

118. D.47.10.13.7. 
relationship. Since the statement that innkeepers must accept travelers was in the form of an explanation for a rule which was accurate, the compilers did not focus on whether the explanation was the right rulein other words, they did not have any reason to pull together all passages relating to the obligation to serve and try to make them consistent. The only concern they had was whether the statement on the duty to serve was incorrect. In the absence of any definitive ruling, there was a sufficient argument for such a duty to prevent its unequivocal rejection.

\section{Conclusion}

The simple attempt to determine whether innkeepers in ancient Rome had a legal obligation to accept travelers began with an apparent conflict in the text of the Digest. Unraveling that conflict involved an excursion into the development of Roman law, the way in which texts were preserved and how the Digest was constructed. This exploration concludes that the conflict resulted from the failure of the Roman jurists to engage in just such an historical study. Instead, they tried to explain the law on liability by extrapolations from other legal principles. This abstract ahistorical reasoning produced confident statements of directly opposite propositions on an undecided point, resulting in total confusion in the Digest.

The power to reject customers is not a good reason for imposing strict liability. The mistaken rationale in the Digest could have discouraged the imposition of a duty to serve the public by fostering a belief that a duty to serve the public requires lowering liability standards. Similarly, the attribution of fault to the operator of a business in selecting employees could have preserved a penalty beyond its useful period. The division and dissolution of the Roman empire, however, prevented any further immediate development along these lines.

This article not only points to the problems of ignoring history in dealing with current issues, but it begins in one small area the process of looking at historical development. The common law principle that hotels, restaurants and common carriers have a status-based responsibility to the public has been an important element in the development of race relations law in the United States. ${ }^{119}$ The Romans probably would have decided in favor of the innkeeper's right to exclude travelers from the inn. Although similarities between the common law and Roman law can lead the scholar to find common sources for

119. See Note, "The Antidiscrimination Principle in the Common Law," 102 Harv. L. Rev. 1993 (1989); Randall Kennedy, "Martin Luther King's Constitution: A Legal History of the Montgomery Bus Boycott," 98 Yale L. J. 999 (1989); Heart of Atlanta Motel v. United States, 379 U.S. 241 (1964); Katzenbach v. McClung, 379 U.S. 294 (1964); The Civil Rights Cases, 109 U.S. 3 (1883); Plessy v. Ferguson, 163 U.S. 537 (1896). 
obligations, here it is the differences that provide insight. ${ }^{120}$ Roman law reveals that the obligation of the innkeeper or the common carrier to serve the public is not necessarily an integral part of their status. The law may impose strict liability on innkeepers or carriers for loss or damage of their customers' goods without requiring them to accept all comers. Thus, the development of a common law obligation to serve the public does not come from any universal principle, but it is rooted in English experience during the middle ages where it first saw the light of day.

120. When Sir William Jones wrote his treatise on bailments in the eighteenth century, he proposed to illustrate English law by a comparison with foreign law. William Jones, An Essay on the Law of Bailments, Classics of English Legal History in the Modern Era (London: C. Dilly, 1781 reprinted New York: Garland Publishing, Inc. 1978) p. 3. He contended that "a perfect harmony subsists on this interesting branch of jurisprudence in the codes of nations most eminent for legal wisdom, particularly of the ROMANS and the ENGLISH." Id. at 11. "What is good sense in one age," he remarked, "must be good sense, all circumstances remaining, in another." Id. at 14.

Several authors made the mistake of reading Jones' comments on the coincidence of Roman law and English law as a statement that Roman law was the basis for English law on bailments, including innkeepers. Radin, supra note 90 at 254; William L. Burdick, The Principles of Roman Law (Rochester, N.Y.: Lawyers Cooperative Publishing Co., 1938) p. 55. Justice Story also pointed to the Roman Law which made the innkeeper liable for goods delivered to his keeping as the source of the common law of innkeeper liability. J. Story, Commentaries on the Law of Bailments (5th ed., Boston: Little, Brown Co., 1851) pp. 489-95. Indeed, Lord Holt in Coggs v. Bernard, 2 Ld. Ray. 909, 92 E.R. 107 (1703), analyzed the law of bailments based on Bracton [Henry de Bracton, On the Laws and Customs of England (4 vols.; Samuel Thorne, ed.,) 2:284-85.] who in turn drew from Roman law. See Theodore F. T. Plucknett, A Concise History of the Common Law (5th edition; Boston: Little, Brown \& Co., 1956) p. 264. Whether English law on innkeepers was influenced by Roman law remains controversial: its main features predate Holt's use of Bracton. At the least, Roman law illustrates some of the legal issues involving innkeepers and provides a basis for comparison which assists in understanding why English law developed as it did. 